\title{
HYPERTENSION, METABOLIC DERANGEMENTS AND RENAL DYSFUNCTION IN RENAL TRANSPLANT PATIENTS USING CYCLOSPORINE OR TACROLIMUS
}

\author{
Alterações metabólicas, hipertensão arterial e função renal em transplantados renais com o uso de \\ Tacrolimo ou Ciclosporina
}

Luiz Estevam lanhez, David José de Barros Machado

\begin{abstract}
Purpose: To assess metabolical and hypertension adverse events and renal function outcomes in patients with renal transplant receiving neoral cyclosporin or tacrolimus in an outpatient service in B razil. Methods: A II consecutive patients with renal transplant performed at Hospital A lemão O swaldo C ruz between M arch 2000 and December 2003 were enrolled. Patients were divided in groups I with 24 patients taking tacrolimus and II with 23 patients taking neoral cyclosporin. It was compared their metabolical and hypertension adverse events and renal function outcomes. Results: B oth groups presented comparable outcomes at baseline related to age, gender, race, end-stage renal disease and weight. Serum total cholesterol (186.6 $\pm 42 \times 244.1 \pm 48.1 \mathrm{p}=0.002 ; \mathrm{mg} / \mathrm{dl})$, low-density lipoprotein (LDL) cholesterol (98.01 $\pm 23.3 \times 153.2 \pm 41.5 p=0.011 ; \mathrm{mg} / \mathrm{dl})$ and triglyceride $(181.2 \pm 91.1 \times 292.5 \pm 258.1-p=0.012 ; \mathrm{mg} / \mathrm{dl})$ were significantly lower in patients receiving tacrolimus than those on cyclosporin. The antihyperlipidaemic medication to control lipid levels required by the cyclosporin group was strongly greater ( 70 vs $26 \%, p=0.04$ ). Significantly more patients on cyclosporin than on tacrolimus presented hy pertension ( 60 vs $17 \%, p=0.009$ ). Post-transplant diabetes mel litus frequency showed no difference between groups ( $24.1 \mathrm{vs} 16.6 \%)$. The serum creatinine level at the third month of tacrolimus treated patients was significantly lower than the cyclosporin treated patients (1.15 0.21 vs $1.40 \quad 0.38$; $p=0,009)$. Conclusion: Patients receiving maintenance immunosuppression with tacrolimus as opposed to ciclosporin present better renal function and reduced cardiovascular risk factors.
\end{abstract}

Keywords: Cyclosporine, Tacrolimus, Dyslipidaemias, Hypertension, Diabetes M ellitus.

Instituição:

Serviço de Transplante Renal do Hospital Alemão 0swaldo Cruz, São Paulo - SP

Correspondência:

Luiz Estevam lanhez

Rua João Julião, 331

CEP 01323-903 - São Paulo - SP - Brasil

Fone: (11) 3549-0000

E-mail: leianhez@aol.com

Recebido em: 24.01.2006
Aceito em: 20.04.2006

\section{INTRODUCTION}

Tacrolimus is the last calcineurin inhibitor approved for clinical use to prevent acute rejection against renal allograft. Comparison studies of calcineurin inhibitors as cornerstone immunosuppressants in renal transplantation have demonstrated that tacrolimus consistently reduces acute rejection rates and, in some studies, it also improves long-term renal outcome compared to cyclosporin A (CsA).

A Iso, it has shown to be superior to cyclosporin with lesser nephrotoxicity, lesser cardiovascular adverse events (less hypertensive effect and less hypercholesterolaemia) although it increases the risk of post-transplant diabetes mellitus (PTDM ). ${ }^{1,2,3,4}$

The two leading causes for the late renal allograft loss are chronic allograft nephropathy and death with a functioning graft4, which are determined by previously enlisted factors, including acute and chronic rejection, renal function and cardiovascular risk factors. Therefore, the use of tacrolimo can extend renal survival. 2,3,4

Our purpose was to evaluate metabolical and hypertension adverse events and renal function outcomes in patients with renal transplant receiving neoral cyclosporin or tacrolimus in an outpatient service in B razil. 


\section{METHODS}

A II consecutive renal transplant patients followed in an outpatient service by the main author were en rolled. The renal transplantations were performed at H ospital A lemão O swaldo Cruz between $\mathrm{M}$ arch 2000 and December 2003. Patients were divided in two groups, according to the imunossupressor: groups: I, 24 patients taking tacrolimus, and II, 23 patients taking neoral cyclosporin.

It was an open-label, prospective, parallel-group study designed to evaluate either tacrolimus (Prograf $\AA$ ) or cyclosporin-M E immunosuppressive therapy. Patients received adjunctive medication consisting of mycophenolate mofetil (M M F; CellCept $\left.{ }^{\circledR}\right)$ and corticosteroids.

Therapy with calcineurin inhibitors started orally 5 days before transplantation with live donor and immediately before transplantation with deceased donor. The initial dose of tacrolimus was $0.2 \mathrm{mg} / \mathrm{kg}$ twice/day with subsequent dosage adjustments performed to achieve whole-blood trough levels of $10-15 \mathrm{ng} / \mathrm{ml}$ in the first month, and 5-10 ng/ml thereafter. Neoral cyclosporin was administered at an initial daily dose of $8 \mathrm{mg} / \mathrm{kg}$ in two divided doses adjusted to maintain whole-blood trough levels between 250 and $350 \mathrm{ng} / \mathrm{ml}$, and 2-hour level at about $1400 \mathrm{ng} / \mathrm{ml}$ in the first month, and whole-blood trough levels between 150 and $200 \mathrm{ng} / \mathrm{ml}$ and 2-hour level between 800 and $1200 \mathrm{ng} / \mathrm{ml}$ thereafter. Trough blood concentrations were measured by I M x Tacrolimo II assay for tacrolimus and monoclonal antibody assay for cyclosporin.

M M F was administered at an initial dose of $2 \mathrm{~g} /$ day, and azathioprine was given at an initial dose of $2 \mathrm{mg} / \mathrm{kg}$, with subsequent dosage adjustments based on tolerability and adverse effects.

M etilprednisolone (500 mg) was intravenously given immediately before transplantation, and prednisone started at $1 \mathrm{mg} / \mathrm{kg}$ in the 2nd postoperative day and tapered until $0.1 \mathrm{mg} / \mathrm{kg}$ at the end of the second month.

In the third month after transplantation, the total serum cholesterol, high-density lipoprotein (HDL) cholesterol, low-density lipoprotein (LDL) cholesterol; triglyceride and homocysteine levels were recorded. Patients were weekly evaluated in the first two post-transplantation months, with creatinine and calcineurin inhibitor serum levels measured the day before the medical visit. Glucose and urinalysis were done every two-weeks or as necessary. A rterial pressure and weight were recorded in all medical visits.

The study was undertaken in accordance with the Declaration of Helsinki. Informed consent was obtained from all participants.

[Chi]2 and Fisher's exact tests were used to compare categorical variables. The M ann-W hitney U -test and "t test" were used to compare continuous variables. For all statistical tests, P-values of $<0.05$ were considered statistically significant. M ean values are given with SDs.

\section{RESULTS}

Both groups were comparable at the baseline as to age, gender, race, end-stage renal disease, and weight. Demographic data are summarized in Table I.

By the third month, patients enrolled had immunosupressive regimen compared the donor type. It was found no differences between both groups' doses data (Table II), except as to the M M F doses which were smaller in group I.
Table I: Demographic data

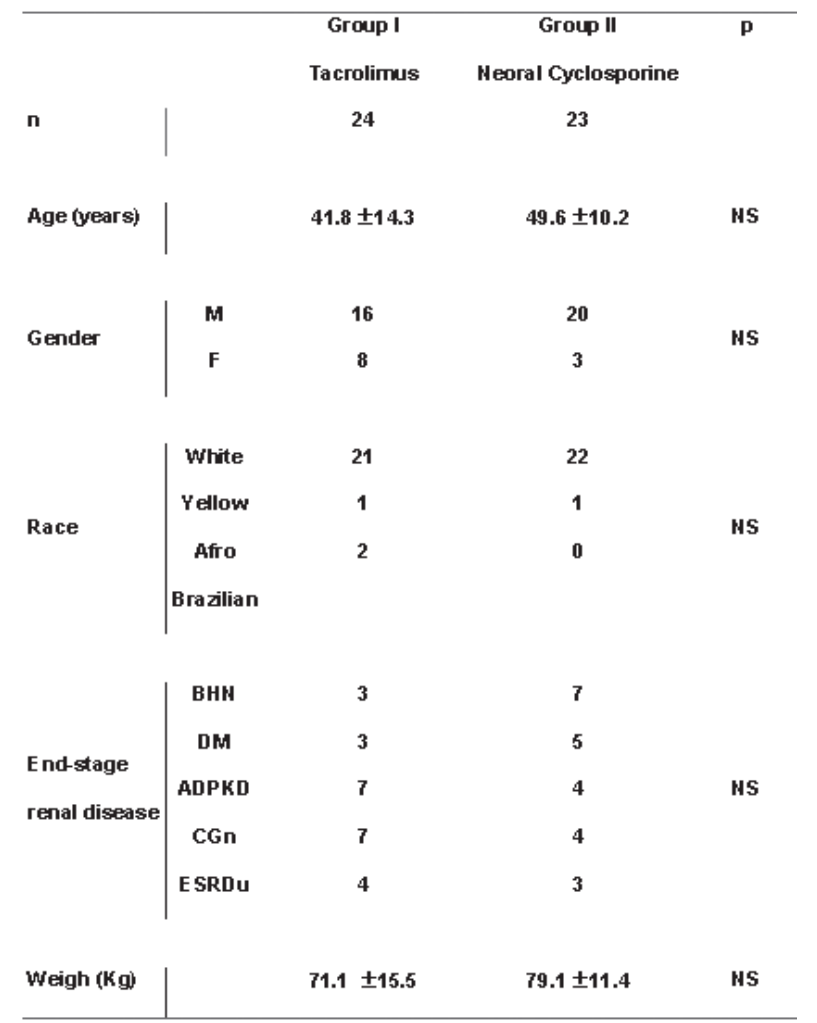

BHN - begin hypertensive nephrosclerosis; DM - diabetes mellitus nephropathy; ADPKD - autosomal dominant polycystic kidney disease; CGn - Chronic glomerolophritis; ESRDue - end-stage renal disease of unknown etiology.

Table II- Immunosupressive regimen by the donor type and differences between the two groups doses data.

\begin{tabular}{|c|c|c|c|c|}
\hline & & Group I & Group II & $p$ \\
\hline \multirow{3}{*}{ Donor } & UD & 15 & 14 & \multirow[t]{3}{*}{ NS } \\
\hline & $\mathrm{RD}$ & 7 & 8 & \\
\hline & DD & 2 & 1 & \\
\hline \multirow{3}{*}{ Drugs } & AZA & 5 & 10 & \multirow[t]{3}{*}{ NS } \\
\hline & MMF & 19 & 11 & \\
\hline & without AZA or MMF & 0 & 2 & \\
\hline \multirow{3}{*}{ Doses } & Prednisone mg/kg & 0.11 & 0.11 & NS \\
\hline & MMF mg/kg & $19.2 \pm 4.9$ & $21.9 \pm 4.2$ & 0,04 \\
\hline & AZA mg/kg & $1.7 \pm 0.29$ & $1.7 \pm 0.5$ & NS \\
\hline
\end{tabular}

UD - Unrealated donor; RD - Related donor; DD - Deceased donor; $\boldsymbol{A Z A}$ - Azathioprine; MMF - Mycophenolate Mofetil.

Mean doses and whole-blood trough levels of tacrolimus and cyclosporin at third month are shown in Table III. No patients required any change in their immunosuppressive therapy. 
Table III - Mean doses and whole-blood trough levels of tacrolimus and cyclosporin

\begin{tabular}{lcc}
\hline & Tacrolimus & Neoralcyclosporin \\
\hline Doses $(\mathrm{mg} / \mathrm{kg})$ & $0.10 \pm 0.05$ & $3.02 \pm 0.56$ \\
Range $(\mathrm{mg} / \mathrm{d})$ & $0.03-0.17$ & $1.8-4.0$ \\
\hline Serum Levell $(\mathrm{ng} / \mathrm{ml})$ & $7.5 \pm 2.7$ & $173.7 \pm 25.4$ \\
Range $(\mathrm{ng} / \mathrm{ml})$ & $3-11$ & $94-264$ \\
\hline
\end{tabular}

Serum lipid levels and homocysteinaemia are presented in Figure I. Total serum cholesterol, low-density lipoprotein (LDL) cholesterol and triglyceride were significantly lower in patients receiving tacrolimus than those on cyclosporin. There were no differences in HDL cholesterol levels between groups.

Figure I - Serum lipid levels and homocysteinaemia. Serum total cholesterol, low-density lipoprotein (LDL) cholesterol and triglyceride were significantly lower in patients receiving tacrolimus than those

on cyclosporin.

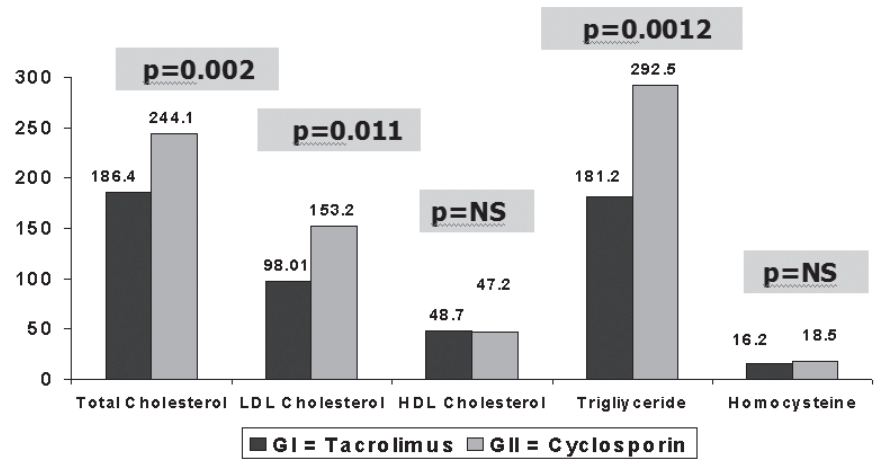

F requency of patients with lipid disturbances as to III Diretrizes Brasileiras sobre Dislipidemia da Sociedade Brasileira de Cardiologia categorized as total serum cholesterol $>200 \mathrm{mg} /$ dl, LDL cholesterol $>100 \mathrm{mg} / \mathrm{dl}, \mathrm{HDL}$ cholesterol $<40 \mathrm{mg} / \mathrm{dl}$ and triglyceride $>150 \mathrm{mg} / \mathrm{dl}$ are presented in Figure II. Fewer than $1 / 3$ of tacrolimus treated patients and greater than $2 / 3$ of cyclosporin treated patients had lipid disturbances and the antihyperlipidaemic medication to control lipid levels required by the cyclosporin group was strongly greater.

Figure II - Frequency of patients with lipid disturbances according to the III Diretrizes Brasileiras sobre Dislipidemia da Sociedade Brasileira de Cardiologia. Data are categorized as serum total cholesterol $>200$ $\mathrm{mg} / \mathrm{dl}$, LDL cholesterol > $100 \mathrm{mg} / \mathrm{dl}$, HDL cholesterol $<40 \mathrm{mg} / \mathrm{dl}$ e triglyceride $>150 \mathrm{mg} / \mathrm{dl}$.

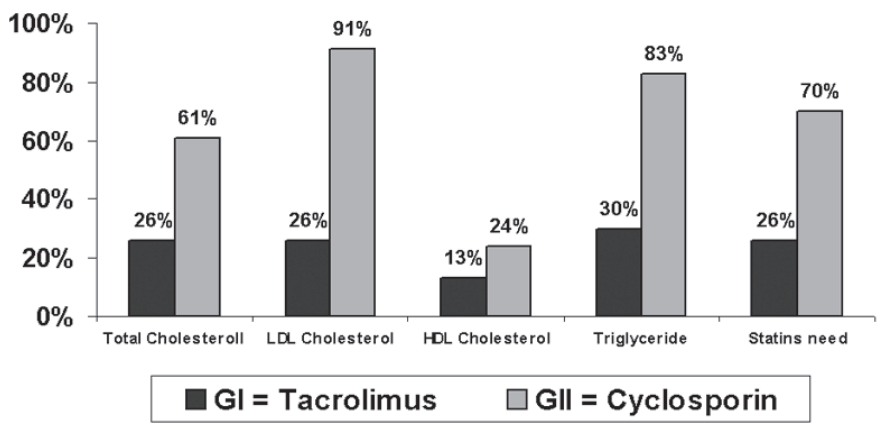

Frequency of patients presenting hypertension and posttransplant diabetes mellitus are shown in Figure III. Significantly more patients on cyclosporin than on tacrolimus presented hypertension.

Figure III - Frequency of patients presenting hypertension and posttransplant diabetes mellitus.

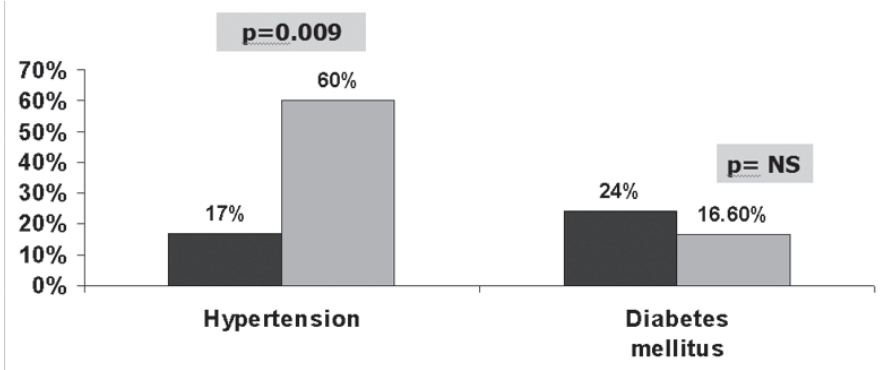

The serum creatinine level at the third month of tacrolimus patients was significantly lower than the cyclosporin patients $(1.15 \pm 0.21$ vs $1.40 \pm 0.38 ; p=0,009)$. A llograft rejection incidence was not different between groups (20\%); there was no early graft Ioss. A II PTDM cases were treated with oral hypoglycemic drugs; there were no need of using insulin. Post-transplant diabetes mellitus in tacrolimus patients were diagnosed in 4 patients in the first month and in 1 patient at the 2nd month. Patients on cyclosporin presented PTDM at the 1st, 3rd, 15th and 36th month. Two PTDM cases on tacrolimus were transient.

\section{DISCUSSION}

Data from multicentric and from the author's studies had al ready proved that tacrolimus is more efficient than cyclosporin to reduce rejection crises and in preservating the renal function1-3. In this study, although enrolling a small number of patients followed by the main author, it was confirmed other advantages of tacrolimus previously reported in the international literature ${ }^{4-7}$.

A ttaining long-term graft survival and optimal patient health are ultimate clinical goals in renal transplantation. M any factors have negative impact on long term transplant outcomes, including graft rejection, renal dysfunction and increased cardiovascular burden. Glucose metabolism disturbance, also a cardiovascular risk factor, influences the morbidity and mortality. A s such, careful consideration on the immunosuppressive strategy and its impact on these factors is critical to optimize outcomes.

Significant improvements in short-term graft survival have been attained over the last decade, in part due to more effective immunosuppressive regimens with the induction therapy and the newer maintenance drugs, such as the calcineurin inhibitor tacrolimus, but also as a result of a better understanding of monitoring drug levels and risk factors that impact graft survival. A cute rejection incidence is reducing, and chronic allograft nephropathy and death with a functioning graft are the two leading causes of late renal al lograft loss. $., 8,9$

A s we are engrafting older patients, cardiovascular disturbances seems to be the most important cause of the late renal al lograft loss or death with a functioning renal allograft. So, it must be selected drugs with lesser cardiovascular and metabolic adverse events to reduce the cardiovascular burden and enhance patient survival. 
Hyperlipidaemia, hypertension, advanced age, compromised renal function are known factors that intervene to the renal transplant patients' survival10. In the present B razilian study, it was clearly show $n$ that the interference of tacrolimus in the lipid metabolism of renal transplant patients were lower than the cyclosporin's, as the serum cholesterol, LDL cholesterol and triglycerides levels had been significantly lower in patients receiving tacrolimus. N evertheless, the percentage of patients with tacrolimus that needed statins was significantly lower than that of cyclosporin treated patients.

A Dutch crossover study evaluating 17 renal transplant patients with more than one year follow-up to which the neoral cyclosporin was substituted by tacrolimus in the $0.2 \mathrm{mg} / \mathrm{kg}$ dose per day per 4 weeks and repeated measurements of serum cholesterol level, HDL cholesterol, LDL cholesterol, triglycerides were done at the beggining of tacrolimus, after 4 weeks on tacrolimus and after 4 weeks on a new use of the same dose of cyclosporin, showed that during the use of tacrolimus there was a significant reduction in the cholesterol and LDL cholesterol levels ${ }^{5}$.

The lower levels of lipids and minor need of statins in patients receiving tacrolimus bring in consequences lower cardiovascular risk and lesser cost for the maintenance of the patients.

Notorious is the maleficent influence of the arterial hypertension in renal transplant patient and allograft survival ${ }^{11}$.

We found that only $17 \%$ of patients on tacrolimus had hypertension against $60 \%$ receiving cyclosporin certifies the lower hypertensive effect of tacrolimus compared to cyclosporin. Such data was well-demonstrated in the Dutch study by ambulatory blood pressure monitoring, in which steady patients on cyclosporin moved to tacrolimus. ${ }^{5}$

The most important metabolic derangement imputed to tacrolimus is the higher incidence of diabetes mellitus. PTDM etiology is diverse. For better understand the PTDM causes, a review of the subject 12 is suggested as it is out of the scope of this article. Briefly, attention should be paid to the age, race, history of diabetes, index of corporal mass, dose of corticosteroids, use of high doses of metylprednisolone, cytomegalovirus infection, cyclosporin and tacrolimus use.

Surprisingly, PTDM developed in $16.6 \%$ of patients on cyclosporin and in $24 \%$ of patients under tacrolimus in our casuistic. M any U.S. and European centers reported the incidence of PTDM in renal transplant patients which ranged from $4.8 \%$ to $9.8 \%$ using cyclosporin and from 6.5 to $18.5 \%$ using tacrol imus ${ }^{13,14,15,16}$. It must be observed that the tacrolimus levels we used were lower than previously considered the normal range for clinical use minimizing the risk. It was show $n$ data on the beginning of the PTDM comparable to the literature: tacrolimus treated patients' PTDM occured soon after the transplant (2.1months) unlike the beginning of the PTDM for cyclosporin treated, which was later (27.0 months) in the Romagnoli et al. study16. O ur patients under tacrolimus developed PT DM in the first 2 months of therapy, and patients using cyclosporin presented PTDM more often after the third month.

As to the glucose metabolism, the only significant difference between patients receiving tacrolimus and those receiving cyclosporin is related to the pancreatic secretion capacity at the 3rd after-transplantation week, when the increment of $\mathrm{C}$-peptide secretion is $57 \%$ lower, and the increment of insulin secretion is $48 \%$ lower in patients receiving tacrolimus. In both groups, from week 3 to month 6 , there was a tendency toward an increasing insulin sensitivity index, despite a significant increase in fasting glucose and insulin resistance calculated by homeostasis model assessment. After month 6 , there were no significant changes in any of the parameters of the glucose metabolism, indicating that long-term use of either tacrolimus or cyclosporin does not cause chronic, cumulative pancreatic toxicity ${ }^{14}$. C uriously, the incidence of PTDM seems to be higher in hepatits $C$ patients receiving tacrolimus ${ }^{13,17}$. So far, it can be concluded that the diabetogenic effect of tacrolimus is not of great concern, and it can be managed by reducing the dose of tacrolimus, early corticosteroid withdrawal and avoiding it in hepatits $C$ patients ${ }^{18}$.

Hyperhomocysteinaemia was not seen under the use of tacrolimus compared to cycloprin, as previously reported ${ }^{19,20}$.

The lower serum creatinine levels at the third month observed in patients receiving tacrolimus compared to cyclosporin with the same doses of azathioprine, M M F and prednisone, suggest that tacrolimus is a better imunossupressor to prevent subclinial acute rejection and is also less nephrotoxic ${ }^{21,22}$.

\section{CONCLUSION}

Tacrolimus is the cornerstone immunosuppressant of choice for renal transplantation. Patients receiving maintenance immunosuppression with tacrolimus as opposed to ciclosporin have better renal function and reduced cardiovascular risk factors. Together, these findings may ge translated to improved long-term transplant outcomes with tacrolimus, as already g documented by record of analysis.

\section{RESUMO}

Objeivo: Avaliar os eventos metabólicos adversos de hipertensão arterial e o resultado da função renal de pacientes transplantados renais recebendo ciclosporina neoral ou tacrolimo em um serviço ambulatorial no B rasil. Métodos: Todos pacientes consecutivos com transplante renal realizado no Hospital A lemão Oswaldo Cruz entre março/2000 e dezembro/2003 foram englobados neste estudo. Dividimos os pacientes em grupos I (24 pacientes tomando tacrolimo) e II (23 pacientes tomando ciclosporina neoral). Comparamos os eventos metabólicos adversos de hipertensão arterial e o resultado da função renal. Resultados: Os dois grupos eram comparáveis no início do estudo referente a idade, sexo, raça, doença renal primária e peso. Os níveis de colesterol total (186,6 $\pm 42 \times 244,1 \pm 48,1$ $p=0,002 ; \mathrm{mg} / \mathrm{dl}), \operatorname{LDL}(98,01 \pm 23,3 \times 153,2 \pm 41,5 \mathrm{p}=0,011 ; \mathrm{mg} / \mathrm{dl})$ e triglicérides $(181,2 \pm 91,1 \times 292,5 \pm 258,1-p=0,012 ; \mathrm{mg} / \mathrm{dl})$ foram significativamente menores no grupo tacrolimo do que no grupo ciclosporina. A necessidade do uso de hipolipemiantes foi maior no grupo da ciclosporina (70 vs $26 \%, p=0,04)$. M ais pacientes usando ciclosporina apresentaram hipertensão arterial $(60$ vs $17 \%, p=$ 0,009). A freqüência de diabetes mellitus não foi diferente entre os dois grupos (24,1 vs $16,6 \%)$. 0 nível sérico de creatinina no terceiro 
mês nos pacientes usando tacrolimo foi significativamente menor do que em pacientes tomando ciclosporina $(1,15$ vs 1,4 - $p=0,009$; mg/dl). Conclusão: Pacientes recebendo imunossupressão de manutenção com tacrolimo, comparados com os que usam ciclosporina têm melhor função renal e menos fatores de risco cardiovascular.

Descritores: Ciclosporina, Tacrolimo, Dislipidemias, Hipertensão, Diabetes M ellitus.

\section{REFERENCES}

1. Ianhez LE. Tacrolimo: agente imunossupressor primário no transplante renal. Prática Hospitalar. 2002;24:19-23.

2. Margreiter R. For the European tacrolimus vs ciclosporin microemulsion renal transplantation study group - Efficacy and safety of tacrolimus compared with ciclosporin microemulsion in renal transplantation: a randomised multicentre study. Lancet. 2002;359:741-6.

3. Vicenti F, Jensik SC, Filo RS, et al. A long-term comparison of tacrolimus (FK506) and cyclosporine in kidney transplantation: evidence for improved allograft survival at five years. Transplantation. 2002;73:775-82.

4. Pascual M, Theruvath T, Kawai T, Tolkoff-Rubin N, Cosimi AB. Strategies to improve long-term outcomes after renal transplantation. N Engl J Med. 2002;346:580-90.

5. Ligtenberg G; Hené RJ; Blankestijn PJ, et al. Cardiovascular risk factors in renal transplant patients: Cyclosporin A versus tacrolimus. J Am Soc Nephrol. 2001;12:368-73.

6. Hricik DE. - Hyperlipidemia in renal transplant recipients. Cardiovascular disease after renal transplantation. Graft. 2000;3:177-84.

7. Danovitch GM. Immunosuppressant-induced metabolic toxicities Transplantation Reviews. 2000;14(2);65-81.

8. Ojo AO, Hanson JA, Wolf RA, et al. Long term survival in renal transplant recipients with graft function. Kidney Int. 2000;57:307-13.

9. Jardine A. Assessing cardiovascular risk profile of immunosuppressive agents. Transplantation. 2001;72:SS81-7.

10. Ianhez LE. Transplante renal seguimento a longo prazo. In: Lemos Editorial. Nefropatia crônica do enxerto e imunossupressão. São Paulo. 2002. p. 131.

11. Ianhez LE. Transplante renal seguimento a longo prazo. In: Lemos Editorial. Hipertensão arterial. São Paulo. 2002. p. 69.
12. Ianhez LE. Transplante renal seguimento a longo prazo. In: Lemos Editorial. Alterações metabólicas no pó-transplante renal. São Paulo. 2002. p. 33.

13. Bloom RD, Rao V, Weng F, et al. Association of hepatitis $\mathrm{C}$ with posttransplant diabetes in renal transplant patients on tacrolimus. J Am Soc Nephrol. 2002;13:1374-80,.

14. Van Duijnhoven, EM, Christiaans MHL, Boots JMM, et al. Glucose metabolism in the first 3 years after renal transplantation in patients receiving tacrolimus versus cyclosporine-based immunosuppression. J Am Soc Nephrol. 2002;13:213-20,

15. Gonwa T, Mendez R, Yang HC, et al. Randomized trial of tacrolimus in combination with Sirolimus or mycophenolate mofetil in kidney transplantation: results at 6 months. Transplantation. 2003;75:1213-20,

16. Romagnoli J, Citterio F, Violi P, et al. Post-transplant diabetes mellitus: a case-control analysis of the risk factors. Transplant International. 2005;18(3): 309-12.

17. Baid S, Tolkoff-Rubin, N Farrel, ML, et al. Tacrolimus-associated posttransplant diabetes mellitus in renal transplant recipients: role of hepatitis $\mathrm{C}$ infection. Transplantation Proceedings. 2002;34:1771-3.

18. Backman LA. Post-transplant diabetes mellitus: the last 10 years with tacrolimo. Nephol Dial Transplant. 2004 Dec;19 Suppl 6:vi13-vi16.

19. Machado DJB, et al. Hyperhomocyst (e) inemia in chronic stable renal transplant patients. Rev Hosp Clín Fac Med S. Paulo. 2000;55:161-8.

20. Krmar RT, Ferraris JR, Ramirez JA, et al. Hyperhomocysteinemia in stable pediatric, adolescents, and young adult renal transplant recipients. Transplantation. 2001;71:1748-51.

21. Moresco F, Seeon D, Carre RA, M Gil-Vernet S, Cruzado JM; Huejo MRS et al. Base line imunossupression is associated with histological findings in early protocol biopsies. Transplantation. 2004;78:1064-8

22. Pascual J, Marcen R, Ortuño J. Renal function: Defining long-term success. Nephrol Dial Transplant. 2004 Dec;19 Suppl 6:vi3-vi7. 